\title{
Comparative evaluation of the effects of epidural morphine and $0.9 \%$ sodium chloride on cardiorespiratory function and anesthestic recovery in ponies
}

\author{
Avaliação comparativa entre os efeitos da morfina e da solução salina $0,9 \%$ epidurais sobre a função \\ cardiorespiratória e a recuperação anestésica em pôneis
}

\author{
Cláudio Corrêa Natalini ${ }^{1}$, Nadia Crosignani ${ }^{2} \&$ Alexandre da Silva Polydoro ${ }^{2}$
}

\begin{abstract}
Epidural analgesia is an effective technique to treat acute and chronic pain as well as to provide preemptive, intraoperative, and postoperative analgesia. This study was performed to evaluate the effects of epidurally injected morphine and a control group that received $0.9 \%$ sodium chloride. Eighteen healthy male adult ponies were studied. Two groups of 9 were formed. Group M (morphine) received $0.1 \mathrm{mg} / \mathrm{kg}$ morphine diluted up to $5 \mathrm{ml}$ in sterile water, injected at the first intercoccygeal intervertebral space. Group S (saline) received $5 \mathrm{ml}$ of sterile $0.9 \%$ sodium chloride. All animals received $1 \mathrm{mg} / \mathrm{kg}$ xylazine IV for sedation, were induced with $5 \%$ guaifenesin at $55 \mathrm{mg} / \mathrm{kg}$ and $5 \%$ thiopental sodium at $4 \mathrm{mg} / \mathrm{kg}$ IV, and maintained with halothane. Orthopedic surgeries on the thoracic limb (desmotomy) and on the pelvic limb (total ostectomy of the metatarsal II bone) were performed. After anesthesia induction, heart rate, respiratory rate, and arterial blood pressure recorded at 15 minutes intervals, for 90 minutes. Recovery times were recorded beginning when the administration of halothane was interrupted. Recovery quality was graded and compared between groups. Data was analyzed with two-way ANOVA and Bonferroni's test, and ANOVA on ranks. Results demonstrated that recovery time was significantly shorter for the saline group, although the recovery quality was better for the morphine group. Epidural morphine does not produce surgical analgesia for the thoracic limbs in ponies. However it does produce for the pelvic limbs. Epidural morphine in ponies produces superior recovery quality when halothane is used as an inhalant anesthetic.
\end{abstract}

Key words: epidural, morphine, ponies, analgesia, halothane.

\section{RESUMO}

A analgesia epidural é uma técnica eficiente para tratamento da dor aguda, crônica, transoperatória e pós-operatória. Este estudo foi realizado para avaliar os efeitos da administração epidural de morfina e um grupo controle com cloreto de sódio $0,9 \%$. Dezoito pôneis adultos, machos foram estudados. Dois grupos de 9 animais foram formados. O grupo M (morfina) recebeu $0,1 \mathrm{mg} / \mathrm{kg}$ de morfina, diluída em $5 \mathrm{ml}$ de água estéril, administrados no primeiro espaço intercoccígeo. $\mathrm{O}$ grupo $\mathrm{S}$ (salina) recebeu $5 \mathrm{ml}$ de $0,9 \%$ de cloreto de sódio. Todos os animais receberam $1 \mathrm{mg} / \mathrm{kg}$ de xilazina por via IV para sedação, foram induzidos com $55 \mathrm{mg} / \mathrm{kg}$ de guaifenesin $5 \%$ e $4 \mathrm{mg} / \mathrm{kg}$ de tiopental sódio 5\% por via IV para indução e mantidos com halotano. Cirurgias ortopédicas no membor torácico (desmotomia) e no membro pélvico (ostéctomia total do II metatarso) foram realizadas. Após indução anestésica, as frequiências respiratória e cardíaca, as pressões arteriais foram registradas a cada 15 minutos por 90 minutos. Os tempos de recuperação foram registrados assim que o halotano foi interrompido. A qualidade da recuperação também foi determinada. Os dados foram analizados estatisticamente e comparados. Os resultados demonstraram que o tempo recuperação foi significativamente menor no grupo salina. A administração epidural de morfina em pôneis, produz analgesia cirúrgica nos membros pélvicos mas não nos membros torácicos e produz melhor qualidade de recuperação.

Descritores: epidural, morfina, pôneis, analgesia, halotano. 


\section{INTRODUCTION}

Epidural analgesia consists of injection of an analgesic drug into the epidural space and action of the analgesic drug on specific receptors found on the spinal cord after diffusion into the region of the dorsal horn of gray matter [3,31]. Epidural analgesia is an effective technique to treat acute and chronic pain as well as to provide preemptive, intraoperative, and postoperative analgesia. Local anesthetic drugs such as lidocaine and bupivacaine produce epidural anesthesia. Phencyclidine derivatives such as ketamine, alpha-2-adrenoceptor agonists such as xylazine and detomidine, and opioid drugs such as morphine, oxymorphone, and butorphanol are commonly used to produce epidural analgesia in veterinary species $[5,18]$. While local anesthetics produce anesthesia by the means of blocking sympathetic, sensory, and motor function at the spinal nerves site, alpha-2-adrenoceptor agonists, ketamine, and opioids, produce highly selective spinal analgesia, exception made for meperidine which in high doses may produce peripheral nerve block [3,6].

Postoperative pain and stress response can be treated and prevented in some cases with regional anesthetic and analgesic techniques, reducing morbidity $[19,23,24,27]$. The most potent pain relieving substances known are opioid analgesics, but these drugs are not extensively used in horses because marked sympathetic stimulation and central nervous system excitation are observed when opioids are administered intravenously in this species. $[3,6,12,14$, 21,22,25,26].

There are studies showing that morphine alone or the combination of morphine and detomidine given epidurally provides profound analgesia for equine hindlimb pain $[15,30]$. The aim of this study was to comparatively evaluate the effects of epidural morphine with a saline control group on the parameters of heart and respiratory rate, arterial blood pressure and recovery time and quality in normal healthy ponies.

\section{MATERIALS AND METHODS}

This study was performed at Louisiana State University, school of Veterinary Medicine. Institutional animal care and use committee evaluation for the proposed study was done and approved. Eighteen normal healthy male intact adult ponies were studied.
These animals were divided in two groups of nine. Body weight was $138.5 \pm 44.2$ for the morphine group and $139.8 \pm 19.6$ for the saline group. Group M (morphine) received $0.1 \mathrm{mg} / \mathrm{kg}$ morphine ${ }^{1}$ diluted up to $5 \mathrm{ml}$ in sterile water, injected at the first intercoccygeal intervertebral space. Confirmation of the adequate epidural space puncture was done using the resistance to air injection and the hanging drop techniques. Whenever blood was withdrawn from the epidural needle, the needle was removed and reinserted. Group $\mathrm{S}$ (saline) received $5 \mathrm{ml}$ of sterile $09 \%$ sodium chloride also epidurally at the same intervertebral space. For the epidural injection a $.91 \mathrm{~mm} \times 6.35 \mathrm{~cm}$ spinal needle ${ }^{2}$ was used. The ponies were fasted for 12 hours, although water was available all time.

All animals received $1 \mathrm{mg} / \mathrm{kg}$ xylazine ${ }^{3} \mathrm{IV}$ for sedation, were induced with $5 \%$ guaifenesin ${ }^{4}$ at $55 \mathrm{mg} / \mathrm{kg}$ and $5 \%$ thiopental sodium ${ }^{5}$ at $4 \mathrm{mg} / \mathrm{kg} \mathrm{IV}$. After induction the ponies had their trachea intubated and connected to the anesthesia machine, and halothane was started at $2,0 \mathrm{~V} \%$ on spontaneous ventilation mode for 10 minutes. After that, halothane expired concentration was maintained at $0,9 \%$ in both groups. If arterial blood pressure and heart rate should increase more than $20 \%$ from baseline, halothane expired concentration was increased to $1.4 \mathrm{~V} \%$ Expired gases were monitored with an anesthesia gas monitor ${ }^{6}$. All ponies received Ringer's lactate solution ${ }^{7}$ intravenously at a rate of $7 \mathrm{ml} / \mathrm{kg} /$ hour. After anesthesia stabilization, the ponies received the epidural drug. The anesthetist in charge was blind to the agent used for the epidural injection. Orthopedic surgeries on the thoracic limb (desmotomy) and on the pelvic limb (splint bone removal) were performed. Before premedication and after anesthesia induction, heart rate, respiratory rate, and arterial blood pressure were recorded at 15 minutes intervals, for 90 minutes. Heart rate (HR), systolic arterial pressure (SAP), diastolic arterial pressure (DAP), mean arterial pressure (MAP) were detected using a noninvasive oscillometric blood pressure monitor $^{8}$ with the cuff placed at the tail base. Cuff diameter to tail circumference ratio was approximately 1:3. Blood pressure measurements were not corrected according to the height of the tail above the heart. Respiratory rate (RR) was determined by counting thoracic and abdominal excursions in 1 minute. Recovery times were recorded in minutes beginning when the administration of halothane was interrupted. Quality 
of recovery was graded as 0 (horse would stand up on one attempt without ataxia or any motor impairment); 1 (horse would stand up on second or more attempts without ataxia or motor impairment); 2 (horse would stand up presenting ataxia or motor impairment); 3 (horse needed assistance to stand up). After recovery the ponies were monitored during 24 hours for subjective and objectives signs of pain such as appetite, bearing weight or not on the surgically operated limb, and respiratory and heart rate. Ponies showing signs of pain received $1.0 \mathrm{mg} / \mathrm{kg}$ of flunixin meglumine ${ }^{9}$ intravenously.

Sample size calculations were made considering a minimum difference of 20 minutes for the anesthesia recovery time between groups, a power of 0.8 with a a value of 0.05 . With these parameters, the minimum sample size calculated was 3 to 5 experimental units for each group. Data was analyzed with two-way ANOVA and Bonferroni's test for the numeric parameters and with ANOVA on ranks for the categorical parameters.

\section{RESULTS}

All epidural injections were done without major difficulties. The spinal needles used were adequate for caudal epidural puncture in ponies. Blood was withdrawn through the spinal needle from one pony on group M. The needle was removed and discharged and another sterile new needle used to perform the epidural puncture. The second attempt was successful. In all other 17 ponies, the access to the epidural space was done in one attempt.

There was no significant difference between groups for body weight, doses of xylazine and thiopental, and surgery time. Heart and respiratory rate and arterial blood pressures decreased with time but without significant difference between groups before surgery and were significantly higher for group $\mathrm{S}$ after surgery started. For group M, heart and respiratory rate and arterial blood pressures were significantly higher then baseline after surgery started on the thoracic limbs (Table 2). The recovery time was significantly shorter for the saline group (Table 1). The quality of recovery was considered superior for the morphine group, with the ponies rolling to sternal recumbency and standing up on their first attempt (Table 1). On the saline group, the ponies presented
Table 1. Recovery quality in ponies after epidural administration of morphine $(0.1 \mathrm{mg} / \mathrm{kg})$ or saline $(0.9 \%)$ for orthopedic surgery ( $n=9 /$ group).

\begin{tabular}{|c|c|}
\hline Variable and group & Data \\
\hline \multicolumn{2}{|c|}{ Mean recory time $( \pm S D)$ in minutes } \\
\hline$S$ & $15,0+3,0^{*}$ \\
\hline M & $30,0+10,0 *$ \\
\hline \multicolumn{2}{|c|}{ Mean attempts to standing $( \pm S D)$} \\
\hline S & $3,0+2,0^{*}$ \\
\hline M & $1,0^{*}$ \\
\hline \multicolumn{2}{|c|}{ Recovery score (grade/number of ponies) } \\
\hline S & $(3 / 9)$ \\
\hline M & $(0 / 9)$ \\
\hline
\end{tabular}

paddling movement before attempting to stand up and were usually ataxic, needing assistance to stand.

\section{DISCUSSION}

The location of the first intercoccygeal vertebral space was easily achieved by moving the tail on a dorsal-ventral pattern as described before [22,23]. Decision to inject the epidural solution was made only when no blood was withdrawn trough the spinal needle placed in the epidural space and there was negligible resistance to the injection of 3 to $5 \mathrm{ml}$ of air as recommended [22]. We assume that all epidural injections were done adequately into the first intercoccygeal epidural vertebral space. In some ponies but not all, the drop of sterile saline was easily observed being aspirated from the needle hub similarly to what has been described [23].

During inhalation anesthesia the potent depressant cardio-respiratory effects of the anesthetic agents in horses and ponies, decreases respiratory and heart rate after 15 minutes [25]. In animals and human beings on halothane anesthesia and spontaneous ventilation it is expected that the arterial partial pressure of carbon dioxide $\left(\mathrm{P}_{\mathrm{a}} \mathrm{CO}_{2}\right)$ builds up with time due to the decrease in tidal volume and respiratory rate, and in cardiac output. This increase in $\mathrm{P}_{\mathrm{a}} \mathrm{CO}_{2}$ produces a sympathetic stimulation increasing the systemic vascular resistance and heart rate $[25,26]$. The respiratory rate did not change significantly from baseline in both groups 


\begin{tabular}{|c|c|c|c|c|c|c|c|}
\hline \multirow[b]{2}{*}{$\begin{array}{l}\text { Variable } \\
\text { and group }\end{array}$} & \multicolumn{7}{|c|}{ Time (minutes after anesthetic induction) } \\
\hline & $\begin{array}{c}\text { Before } \\
\text { premedication }\end{array}$ & 15 & $\begin{array}{c}30 \\
\text { Surgery started } \\
\text { pelvic limbs }\end{array}$ & $\begin{array}{l}45 \\
\text { Surgery started } \\
\text { thoracic limbs }\end{array}$ & $\begin{array}{c}60 \\
\text { Halothane } \\
\text { expired } 1.4 \mathrm{~V} \%\end{array}$ & 75 & 90 \\
\hline \multicolumn{8}{|c|}{ Respiratory rate (breathes/min) } \\
\hline$S$ & $24.2 \pm 17.9$ & $21.1 \pm 9.7$ & $29 \pm 13.6^{*}$ & $38.4 \pm 9.8$ & $19 \pm 2.0$ & $12.1 \pm 5.2$ & $12.6 \pm 2.2^{\pi}$ \\
\hline M & $26.6 \pm 6.7$ & $23.7 \pm 4.8$ & $18.3 \pm 9.6^{\star \llbracket}$ & $35.9 \pm 6.7 \pi$ & $19.8 \pm 6.6$ & $9.4 \pm 3.1$ & $11.3 \pm 1.9^{\pi}$ \\
\hline \multicolumn{8}{|c|}{ Heart rate (beats/min) } \\
\hline S & $73.4 \pm 21.3$ & $100 \pm 25.9$ & $137.4 \pm 36.9^{* \pi}$ & $135.4 \pm 24.2^{\pi}$ & $107.1 \pm 22.6$ & $99.8 \pm 15.1$ & $71.5 \pm 20.3$ \\
\hline M & $75.6 \pm 15.2$ & $102.5 \pm 29.5$ & $105 \pm 19.3^{*}$ & $139 \pm 16.4 \pi$ & $113 \pm 16.3$ & $108.9 \pm 20.8$ & $77.9 \pm 18.9$ \\
\hline \multicolumn{8}{|c|}{ Systolic arterial pressure $(\mathrm{mmHg})$} \\
\hline S & $121.8 \pm 27.6$ & $119.6 \pm 19.1$ & $135.1 \pm 21.7^{\star \pi}$ & $124.1 \pm 26.9$ & $111.6 \pm 18.0$ & $104.6 \pm 19.2$ & $81 \pm 17.5 \pi$ \\
\hline M & $147.2 \pm 10.2$ & $108 \pm 18.4$ & $103.3 \pm 18.3^{*}$ & $121.6 \pm 19.2^{\sharp}$ & $107.7 \pm 20.5$ & $108.6 \pm 24.4$ & $86.9 \pm 21.8^{\sharp}$ \\
\hline \multicolumn{8}{|c|}{ Mean arterial pressure $(\mathrm{mmHg})$} \\
\hline S & $106.2 \pm 32.0$ & $94.3 \pm 18.6$ & $91 \pm 18.5^{\star \pi}$ & $100.3 \pm 22.9$ & $107.3 \pm 17.8$ & $83.7 \pm 12.8^{\star}$ & $65.1 \pm 18.6 \pi$ \\
\hline M & $116.2 \pm 11.9$ & $81.6 \pm 15.2$ & $60 \pm 13.9^{*}$ & $94.3 \pm 18^{4}$ & $108.3 \pm 18.8$ & $85 \pm 19.3^{*}$ & $60.3 \pm 16.9 \pi$ \\
\hline \multicolumn{8}{|c|}{ Diastolic arterial pressure $(\mathrm{mmHg})$} \\
\hline$S$ & $88.8 \pm 25.2$ & $77.7 \pm 21.0$ & $80.4 \pm 20.2^{*}$ & $87.8 \pm 21.1^{\pi}$ & $73.9 \pm 16.9$ & $73 \pm 14.4$ & $53.7 \pm 21.6 \pi$ \\
\hline M & $99.4 \pm 14.6$ & $72.7 \pm 14.6$ & $69.4 \pm 10.2^{*}$ & $76.9 \pm 21.5 \pi$ & $67.7 \pm 19.8$ & $72.4 \pm 19.4$ & $59 \pm 13.8^{\pi}$ \\
\hline
\end{tabular}

before surgery started. This can be explained because in spite of halothane respiratory depression, generally increasing in $\mathrm{P}_{\mathrm{a}} \mathrm{CO}_{2}$ stimulates respiration to compensate the respiratory acidosis [25]. Although morphine is a potent respiratory depressant in human beings when epidurally administered, this effect has not been showed in animals [26,27]. In our study, there was not an effect of morphine on the respiratory rate once there was no significant difference between groups $M$ and $S$. Surgical stimulation on pelvic limbs did not produce significant changes for cardiovascular parameters in group $\mathrm{M}$, but did for the saline group, demonstrating an analgesic effect of epidurally administered morphine. There has been studies demonstrating the analgesic effects of epidurally administered morphine and $\mathrm{OP}_{3}$ opioids in horses [22]. When surgical stimulation was initiated on the thoracic limbs, there were an increase in heart and respiratory rate as well as arterial blood pressure in both groups, clearly showing a lack of surgical analgesia when epidurally administered morphine is used in ponies. Similar results were demonstrated before our study [4].
Epidural morphine has been proved to decrease the halothane minimum alveolar concentration for both thoracic and pelvic limbs in dogs [29]. In ponies that received $0.1 \mathrm{mg} / \mathrm{kg}$ epidural morphine, the MAC for halothane was decreased for the pelvic limb but not for the thoracic limb, using a supramaximal electrical noxious stimulation [30]. Although reduction in MAC was not measured in this study, the halothane concentration with which ponies were maintained $(1.4 \mathrm{~V} \%)$ indicated there was no sparing effect with epidural morphine, as demonstrated before [4]. It is fair to speculate that because surgery was performed on the thoracic limb, the cranial migration of the epidural morphine did not produce enough activation of the Mu-opioid receptors at the thoracic and cervical level of the spinal cord to provide analgesia up to the thoracic limb. Results from this study and others substantiate the conclusion that epidural morphine does not decrease the minimum alveolar concentration of halothane in ponies when there is noxious stimulation of the thoracic limb. 
Recovery quality was significantly superior for the morphine group compared to the saline group. In human beings epidural morphine provides prolonged and satisfactory analgesia in the postoperative period [31]. Recovery after 5-7 hours of halothane anesthesia in ponies that received $0.1 \mathrm{mg} / \mathrm{kg}$ epidural morphine was uneventful and the ponies were standing within 30 minutes after discontinuing anesthesia [30]. In our study mean time for standing position was 76.3 minutes in the morphine group and 31.3 minutes in the saline group. This can be explained by the onset time and long lasting effect of epidural morphine. In horses, onset time for epidural morphine varies from 1 to 4 hours, lasts from 8 to 19 hours, and produces profound sedation [24]. Epidural morphine potentially produced a sedative effect and prolonged the anesthesia recovery time. The sedative effect of epidural morphine could also be responsible for the less disturbing recovery observed in group $\mathrm{M}$.

\section{CONCLUSIONS}

The results of this study indicate that $0.1 \mathrm{mg} / \mathrm{kg}$ epidural morphine does not produce surgical analgesia for the pelvic limbs in ponies. However it does produce for the thoracic limbs. Epidural morphine in ponies produces superior recovery quality when halothane is used as an inhalant anesthetic. It is suggested that a similar study should be done in horses.

\section{SOURCES AND MANUFACTURERS}

${ }^{1}$ Abbott Laboratories. North Chicago, IL/USA.

${ }^{2}$ Spinal needle quincke type point - Becton Dickison and Co. Franklin Lakes, NJ/USA.

${ }^{3}$ Bayer Corporation, Agriculture Division. Shawnee Mission, KS/USA.

${ }^{4}$ Phoenix Pharmaceutical Inc. St. Joseph, MO/USA.

${ }^{5}$ Abbott Laboratories. North Chicago, IL/USA.

${ }^{6} \mathrm{BCI}$ International. Waukesha, WI/USA.

${ }^{7}$ Baxter healthcare Corporation. Deerfield, IL/USA.

${ }^{8}$ Critikon, Inc. Tampa, FL/USA.

${ }^{9}$ Schering-Plough Animal Health Corporation, NJ/USA.

\section{REFERENCES}

1 Combie J., Dougherty J. \& Nugent C.E. 1979. The pharmacology of narcotic analgesics in the horse. IV. Dose and time response repationships for behavioral responses to morphine, meperidine, pentazocine, anileridine, methadone, and hydromorphone. Journal of Equine Medicine and Surgery. 3: 377-385.

2 Combie J., Shults T. \& Nugent E.C. 1981. Pharmacology of narcotic analgesics in the horse: selective blockade of narcoticinduced locomotor activity. American Journal of Veterinary Research. 2: 716-721.

3 Cousins M.J. \& Mather. 1984. Intrathecal and epidural administration of opioids. Anesthesiology. 61: 276-310.

4 Doherty T.J., Geiser D.R. \& Rohrbach B.W. 1997. Effect of high volume epidural morphine, ketamine and butorphanol on halothane minimum alveolar concentration in ponies. Equine Veterinary Journal. 5: 370-373.

5 Farny J., Blais D. \& Vaillancour T.D. 1991. Caudal epidural anesthesia with butorphanol in the mare. In: $4^{\text {th }}$ International Congress of Veterinary Anaesthesia (Utrecht, Netherlands) p.32.

6 Gómez de Segura I.A., De Rossi R. \& Santos M. 1998. Epidural injection of ketamine for perineal analgesia in the horse. Veterinary Surgery. 27: 384-391.

7 Haskins S.C. 1992. Monitoring Support. Veterinary Clinics of North America. Small Animal Practice. 22: 425-434.

8 Karmeling S., Dequick D. \& Weckman T. 1985. Dose-related effects of fentanyl on autonomic and behavioral responses in performance horses. General Pharmacology. 16: 253-258.

9 Leblanc P.H., Caron J.P. \& Patterson J.S. 1988. Epidural injection of xylazine for perineal analgesia in horses. Journal of the American Veterinary Medical Association. 193: 1405-1408.

10 Mathews N. S. 1992. A review of equine pain models. In: Short C. \& Poznak Van A. Animal Pain (Eds). New York: Churchill Livingstone, pp.403-407.

11 Morgan M. 1989. The rational use of intrathecal and extradural opioids. British Journal of Anaesthesia. 63: 165-188.

12 Paddleford R.R. 1999. Analgesia and pain management. In: Manual of small animal anesthesia. 2nd edn. Philadelphia: W.B. Saunders, pp.227-246.

13 Pascoe P.J. 1992. Advantages and guidelines for using epidural drugs for analgesia. Veterinary Clinics of North America. Small Animal Practice. 22: 421-423.

14 Riebold T.W, Geiser D.R. \& Goble D.O. 1995. Large animal anesthesia. 2nd edn. Ames: Iowa State University, pp.205-257.

15 Robinson E.P., Moncada-Suarez J.R. \& Felice L. 1993. Epidural morphine analgesia in horses. In: Annual Meeting of the American College of Veterinary Anesthesiologists. (Washington, USA). p.22.

16 Short C.E. 1995. Equine pain: use of nonsteroidal anti-inflammatory drugs and analgesics for its prevention and control. Equine Practice. 17: 12-22. 
17 Skarda R.T. 1991. Local anesthetics and local anesthetic techniques in horses. In: Muir W.W. \& Hubbell J.A.E. (Eds). Equine anesthesia: Monitoring and emergency therapy. Saint Louis: Mosby, pp.199-246.

18 Skarda R.T. 1996. Local and Regional anesthetic and analgesic techniques. In: Thurmon J.C., William J.T. \& Benson G.J. (Eds). Lumb \& Jones veterinary anesthesia. Baltimore: Williams \& Wilkins, pp.448-478.

19 Skarda R.T. \& Muir W.W. 1994. Caudal analgesia induced by epidural or subarachnoid administration of detomidine hydrochloride solution in mares. American Journal of Veterinary Research. 55: 670-680.

20 Steffey E.P. 1996. Inhalation Anesthetics. In: Lumb W.V. \& Jones E.W. (Eds). Veterinary Anesthesia. 3rd edn. Baltimore: Williams \& Wilkins, pp.297-329.

21 Stoelting R.K. 1999. Opiods Agonists and Antagonists. In: Pharmacology and physiology in anesthetic practice. 3rd edn. Philadelphia: Lippincott-Raven, pp.77-112.

22 Sysel A.M., Pleasant S.R. \& Jacobson J.D. 1996. Efficacy of an epidural combination of morphine and detomidine in alleviating experimentally induced hindlimb lameness in horses. Veterinary Surgery. 25: 511-518.

23 Taylor P.M. 1992. Stress responses to anesthesia in horses. In: Short C. \& Poznak Van A (Eds). Animal Pain. New York: Churchill Livingstone, pp.322-325.

24 Tobin T. 1978. Narcotic analgesics and the opiate receptor in the horse. Journal of Equine Medicine and Surgery. 2: $397-399$.

25 Tobin T. 1981. Drugs and the performance horse. Springfield: Charles C. Thomas Publisher, pp.199-215.

26 Tobin T., Combie J. \& Shults T. 1979. The pharmacology of narcotic analgesics in the horse. III. Characteristics of the locomotor effects of fentanyl and apomorphine. Journal of Equine Medicine and Surgery. 3: 284-288

27 Tobin T., Combie J. \& Shults T. 1979. Pharmacology review: actions of central stimulant drugs in the horse. II. Journal of Equine Medicine and Surgery. 3: 102-109.

28 Tobin T. \& Miller J.R. 1979. The pharmacology of narcotic analgesics in the horse. I. The detection, pharmacokinetics and urinary clearance times of pentazocine. Journal of Equine Medicine and Surgery. 3: 191-198.

29 Valverde A., Dyson D.H. \& McDonell W.N. 1989. Epidural Morphine reduces halothane MAC in the dog. Canadian Journal of Anaesthesia. 36: 629-632.

30 Valverde A., Little C.B. \& Dyson D.H. 1990. Use of epidural morphine to relieve pain in a horse. Canadian Veterinary Journal. 31: 211-212.

31 Yaksh T.L. 1983. The principles behind the use of spinal narcotics. Clinical Anaesthesia. 1: 219-232. 